\title{
Effects on Hematopoiesis in Children Suffering from Iron Deficiency Anemia with Vitamin A Supplementation
}

\author{
Arnab Biswas $^{1 *}$, Isita Tripathy², Kaberi Basu ${ }^{3}$ \\ ${ }^{1 *}$ Assistant Professor, ${ }^{2}$ RMO cum Clinical Tutor, Department of Pediatrics, NRSMCH, Kolkata, WB, India. \\ ${ }^{3}$ Ex Professor, Department of Pediatrics, Medical College, Kolkata, WB, India.
}

\begin{abstract}
Objective: To study the effect of the supplementation of vitamin $\mathrm{A}$ along with standard dose of iron on hematopoiesis in children with documented iron deficiency anemia.

Design: A hospital based prospective study.

Place and Duration: Carried out for 6 months on children with documented iron deficiency anemia in OPD and indoor patients of the department of paediatric medicine, Medical College Kolkata.

Methods: Thirty children (1-12 years age) presenting with iron deficiency anemia (hemoglobin less than $10 \mathrm{~g} / \mathrm{dl}$, mean corpuscular volume $(\mathrm{MCV})<75 \mathrm{fl}$, and serum iron $<55 \mathrm{mcg} / \mathrm{dl}$ ) were studied in two groups of 15 each. Group I was supplemented with iron (ferrous sulphate $3 \mathrm{mg} / \mathrm{kg} / \mathrm{d}$ ) while group II in addition to iron was also supplemented with vitamin A (5000 IU/d). Collected data were expressed as mean +/- SE. Comparison of variables was done by using student $t$ test or chi square test as applicable. $p<0.0001$ was taken as statistically significant.
\end{abstract}

Results: Hemoglobin concentration was found significantly

\section{INTRODUCTION}

Vitamin A deficiency predominantly produces ocular manifestations, which include metaplasia, Bitot's spots, conjunctival and corneal xerosis, and keratomalacia. Extra ocular manifestations include follicular hyperkeratosis, anorexia and growth retardation (Marcus and Coulston, 1996). ${ }^{1}$ Ghatpande et al $(2002)^{2}$ reported that Vitamin A is an important cofactor for normal hematopoiesis though its precise role is difficult to define. Jang et al $(2000)^{3}$ suggested that iron deficiency inhibits mobilization of Vitamin A stores and may decrease its absorption. Role of VitA in iron deficiency was studied in rats ${ }^{4}$ and role of vitamin $A$ deficiency as a contributing factor to anaemia has also been examined in human. ${ }^{5}$ In a study by Gamble MV et al. ${ }^{6}$ among preschool children in the Republic of the Marshall Islands, it was shown that both iron and vitamin A deficiencies were independent risk factors for anemia, but inflammation was not a significant risk factor for anemia among these preschool children. Hashizum et al. ${ }^{7}$ in his study also concluded that anemia among school-aged children in rural Kazakhstan appears to be related to iron indices and vitamin A status. None of the above studies had demonstrated the effect of vitamin A therapy on iron deficiency increased after 4 weeks of iron supplementation. Rise in hemoglobin was comparatively more in-group II, as compared to group I, after 4 and 8 weeks.

Conclusions: The result of this study suggests that supplementation of vitamin A improves hematopoiesis.

Key Words: Vitamin A, Hematopoiesis, Anemia. ${ }^{*}$ Correspondence to:

Dr. Arnab Biswas

563, Fulpukur, Silbagan, PO.Chinsurah

Dist. Hooghly, West Bengal, India.

Article History:

Received: 26-08-2016, Revised: 17-09-2016, Accepted: 23-09-2016

\begin{tabular}{|l|c|}
\hline \multicolumn{2}{|c|}{ Access this article online } \\
\hline $\begin{array}{l}\text { Website: } \\
\text { www.ijmrp.com }\end{array}$ & Quick Response code \\
\hline DOI: & \\
10.21276/ijmrp.2016.2.5.030 & \\
\hline
\end{tabular}

status in children, so it was planned to study the effect of the supplementation of vitamin A along with standard dose of iron on hematopoiesis in children with documented iron deficiency anemia. The study was approved by the ethical committee of medical college and hospital.

\section{MATERIAL AND METHODS}

This prospective study was done for one year on the children in the age group 1-12 year who had attended the outpatient department of Medical College and Hospital, Kolkata due to any reasons. All children with clinically suspected anemia were advised to do a complete hemogram before prescribing any forms of therapy. Iron deficiency anemia is evidenced by hemoglobin less than $10 \mathrm{~g} / \mathrm{dl}$, mean corpuscular volume $(\mathrm{MCV})<75 \mathrm{fl}$, red cell distribution width $(R D W)<10 \mathrm{gm} / \mathrm{dl}$, and serum iron $<55 \mathrm{mcg} / \mathrm{dl}$. Thirty children with documented iron deficiency anemia were studied in two groups of 15 each.

The study protocol was approved by our institutional review board and informed written consent was taken from parents of each patient involved. Children having congestive heart failure, 
symptoms and signs of vitamin A deficiency, children already on iron therapy in any form, unwilling patients or parents were not included. Group I (the control group) was supplemented with iron as ferrous sulphate, at a dose of $3 \mathrm{mg} / \mathrm{kg} / \mathrm{d}$, as a single dose for four weeks. Group II (the study group), in addition to iron (as in group I) was also supplemented with vitamin A (5000 IU/d) for four weeks.

Hemoglobin levels were assayed by Cyanmethemoglobin method before the start and after four weeks of therapy and also after eight weeks. Besides hemoglobin, red cells count, reticulocytes counts, mean corpuscular volume (MCV), serum iron (Higgen, 1981) ${ }^{8}$ were also determined. Collected data were analyzed using statistical package for social sciences (SPSS 11.5) program and expressed as mean $+/$ - SE. Comparison of variables was done by using student $t$ test or chi square test as applicable. $p<0.0001$ was taken as statistically significant.

Table 1: Hemoglobin percentage

\begin{tabular}{lcccc}
\hline Hemoglobin \% & Baseline & End of $4^{\text {th }}$ wk & End of 8 $^{\text {th }}$ wk & P value \\
\hline Control Group (Iron Only) & 9.1 & 9.73 & 10.56 & 0.0001 \\
Study Group (Iron + Vit. A) & 8.46 & 10.09 & 12.37 & $<0.0001$ \\
P Value & 0.0056 & 0.1594 & $<0.0001$ & \\
\hline
\end{tabular}

Table 2: Total RBC count

\begin{tabular}{lcccc}
\hline RBC count & Baseline & End of 4 ${ }^{\text {th }}$ wk & End of 8 th $^{\text {wk }}$ & P value \\
\hline Control group (iron only) & 4.07 & 4.48 & 4.87 & 0.0006 \\
Study group (iron + vit. A) & 4.08 & 4.77 & 5.46 & $<0.0001$ \\
P value & 0.97 & 0.117 & 0.0004 & \\
\hline
\end{tabular}

Table 3: Serum Iron

\begin{tabular}{|c|c|c|c|c|}
\hline Serum Iron & Baseline & End of $4^{\text {th }} w k$ & End of $8^{\text {th }} w k$ & $P$ value \\
\hline Control Group (Iron Only) & 52.01 & 54.42 & 56.99 & $<0.0001$ \\
\hline Study Group (Iron + Vit. A) & 51.08 & 58.40 & 63 & $<0.0001$ \\
\hline P Value & 0.7186 & 0.0007 & $<0.0004$ & \\
\hline
\end{tabular}

\section{RESULTS}

We included 30 children divided into two groups in our study. The baseline parameters to document iron deficiency anemia were same in both groups and as follows,

Hemoglobin less than $10 \mathrm{~g} / \mathrm{dl}$, mean corpuscular volume (MCV) < $75 \mathrm{fl}$, and serum iron $<55 \mathrm{mcg} / \mathrm{dl}$.

Group I (the control group) was supplemented with iron as ferrous sulphate, at a dose of $3 \mathrm{mg} / \mathrm{kg} / \mathrm{d}$, as a single dose for four weeks. Group II (the study group), in addition to iron (as in group I) was also supplemented with vitamin A (5000 IU/d). After $4^{\text {th }}$ and $8^{\text {th }}$ week the same baseline parameters are repeated. (Table 1 , Table 2 and Table 3)

Results of the present study demonstrate that hemoglobin concentration is significantly increased after 4 weeks of supplementation of iron in children. Mean hemoglobin concentrations after 4 and 8 weeks were significantly higher $(p<0.001)$ in-group II that was supplemented with iron and vitamin A, (10.09 and $12.37 \mathrm{~g} / \mathrm{dl}$, respectively) as compared to group I that was supplemented with iron alone $(9.73$ and $10.56 \mathrm{~g} / \mathrm{dl}$ respectively).

\section{DISCUSSION}

Numerous studies using humans have supported the notion that vitamin A has an impact on iron status and, in turn, iron-deficiency anemia, both in human ${ }^{9}$ and in animal like rats. ${ }^{10}$ Early research suggested that people deficient in vitamin A were prone to anemia that was reversed when sufficient doses of vitamin A were taken. A study by Mohanram $M$ et al showed that apart from deficiency of iron, vitamin A deficiency may also have a contributory role in the development of anemia in children. ${ }^{11}$

Another study by Wieringa FT et al. showed that due to redistribution of retinol after iron supplementation, which might induce vitamin A deficiency, iron supplementation in infants should be accompanied by measures to improve vitamin A status. ${ }^{12}$

Many studies in humans have been performed in countries where nutritional anemia and vitamin A deficiency are major public health problems. ${ }^{13}$ One study focused on pregnant women in Indonesia who were anemic due to nutritional status, which the authors reported to affect $50-70 \%$ of all pregnant women in that country. ${ }^{14}$ In another study the relationships between biochemical indicators of vitamin A and iron status and the intestinal helminthes Ascaris lumbricoides and hookworm in primary school children in Bangladesh was explored. ${ }^{15}$

Another study of this type focused on children in Guatemala, with four groups of children receiving either vitamin $A$ or iron or vitamin $A$ and iron or placebo for two months. Various hematological measures were taken, and the results supported an effect of vitamin $A$ on iron status. The major finding in this study was that vitamin $A$ raised the level of serum iron in anemic children, which, according to the authors, could lead to greater hematopoiesis and thus recovery from anemia. Also, the increase in serum iron is maximal when both vitamin $A$ and iron are administered, with either alone resulting in an increase of lesser magnitude. ${ }^{16}$

In a comparable cross-sectional study with children in north-east Thailand, serum retinol was positively associated with haematocrit and serum iron. An association was found between serum retinol and serum transferrin or serum ferritin, but none between serum retinol and haemoglobin. ${ }^{17}$ In a study in Ethiopian children, however, a significant correlation was found between serum retinol levels and haemoglobin.$^{18}$

While these authors imply that nutritional-deficiency anemia might be best treated using both vitamin $A$ and iron, their conclusions are not drawn directly from the hemoglobin data, since there was no significant difference between the iron group and the vitamin $A$ 
and iron group in many studies. Perhaps the observed changes in hemoglobin concentration represent physiological maximums, and the iron available for hematopoiesis, as indicated by serum iron, is greatest when both vitamin A and iron are supplemented in one's diet, even though it may not be used immediately for hematopoiesis.

Suharno et al (1993) demonstrated that there exists a correlation between vitamin $\mathrm{A}$ status and hemoglobin level. ${ }^{14}$ In a study by Zimmerman et al, it was concluded that in children deficient in vitamin $A$ and iron, vitamin $A$ supplementation mobilizes iron from existing store to support increased erythropoiesis, an effect likely mediated by increase in circulating erythropoietin. ${ }^{19}$ Furthermore, addition of retinyl palmitate to iron fortified maize-bread has been reported to enhance the absorption of iron (Davidson et al, 2003)..$^{20}$ Comparatively more rise in hemoglobin with the supplementation of iron along with vitamin A also supports the interaction between iron and vitamin $A$ metabolism even in the present study.

\section{CONCLUSION}

Results of our study showed that supplementation of vitamin A along with standard iron therapy are beneficial in terms of long term outcome in children with documented iron deficiency anemia. Since iron and vitamin A deficiencies are common nutritional problems in this part of the world, it is suggested that both the nutrients should be given simultaneously to overcome the problem of microcytic hypochromic anemia, even if the symptoms and signs of vitamin A deficiency are not apparent.

\section{ACKNOWLEDGEMENTS}

We would like to thank Dr. Eshita Bhowmik and Dr. Sunil Kr Hembram of the Department of Pediatric Medicine, Medical College \& Hospital, Kolkata, 88, college street, kolkata-700041, India.

\section{REFERENCES}

1. Marcus R and Coulston AM. (1996) Fat-soluble vitamins - Vitamin $A, K$ and $E$. In Goodman and Gilman's Pharmacological basis of Therapeutics Eds. Hardman JG, Limbird LE, Motinoff Goodman and Gilman's PB, Ruddon RW and Gilman AG McGraw Hill, New York. p 1573-1590.

2. Ghatpande S, Ghatpande A, Sher J, Zile MH and Evans T. Retinoid signaling regulates primitive (yolk sac) hematopoiesis. Blood 2002, 99:2379-2386.

3. Jang JT, Green JB, Beard JL and Green MH. Kinetic analysis shows that iron deficiency, decreases liver vitamin A mobilization in rats. J Nutr 2000; 130: 1291-1296.

4. Roodenburg AJ, West CE, Hovenier R, Beynen AC. Supplemental vitamin $A$ enhances the recovery from iron deficiency in rats with chronic vitamin A deficiency. Br J Nutr. 1996 pr; 75(4):623-36.

5. Van den Broek N. Anaemia and micronutrient deficiencies.Br Med Bull. 2003;67:149-60.

6. Gamble MV, Palafox NA, Dancheck B, Ricks MO, Briand K, Semba $\mathrm{RD}$. Relationship of vitamin A deficiency, iron deficiency, and inflammation to anemia among preschool children in the Republic of the Marshall Islands. Eur J ClinNutr. 2004 Oct; 58(10): 1396-401.
7. Hashizume M, Chiba M, Shinohara A, Iwabuchi S, Sasaki S, Shimoda T, Kunii O, Caypil W, Dauletbaev D, Alnazarova A. Anaemia, iron deficiency and vitamin A status among school-aged children in rural Kazakhstan. Public Health Nutr. 2005; 8(6):564-71.

8. Higgins T. Novel chromogen for serum iron determination. ClinChem 1981; 27: 1619-1620.

9. Kafwembe EM. Iron and vitamin A status of breastfeeding mothers in Zambia. East Afr Med J. 2001 Sep; 78(9):454-7.

10. Staab DB, Hodges RE, Metcalf WK, Smith JL. J Nutr. Relationship between vitamin A and iron in the liver. 1984 May; 114(5):840-4.

11. Mohanram M, Kulkarni KA, Reddy V. Hematological studies in vitamin A deficient children. Int J VitamNutr Res. 1977;47(4):389-93.

12. Wieringa FT, Dijkhuizen MA, West CE, Thurnham DI, Muhilal, Van der Meer JW. Redistribution of vitamin A after iron supplementation in Indonesian infants. Am J Clin Nutr. 2003 Mar;77(3):651-7

13. Majía LA, Hodges RE, Arroyave G, Viteri F, Torún B.Vitamin A deficiency and anemia in Central American children. Am J ClinNutr. $1977 \mathrm{Jul} ; 30(7): 1175-84$.

14. Suharno $D$, West $C E$, Muhilal $H$, Karyadi $D$ and Hautvast JGAG. Supplementation with vitamin $A$ and iron for nutritional anemia in pregnant women in West Jawa, Indonesia. Lancet 1993; 342: 13251328.

15. Persson V, Ahmed F, Gebre-Medhin M, Greiner T. Relationships between vitamin $A$, iron status and helminthiasis in Bangladeshi school children. Public Health Nutr. 2000 Mar; 3(1):83-9.

16. Mejia LA, Arroyave $G$. The effect of vitamin A fortification of sugar on iron metabolism in preschool children in Guatemala. Am J ClinNutr 1982; 36:87.93

17. Bloem MW, Wedel M, Egger RJ, et al. Iron metabolism and vitamin A deficiency in children in northeast Thailand. Am J ClinNutr 1989; 50:332.338

18. Wolde-Gebriel Z, West CE, Speek AJ, et al. Interrelationship between vitamin $A$, iodine and iron status in school children in Shoa Region, central Ethiopia. Br J Nutr 1993; 70:593.607

19. Michel B Zimmerman, Ralf Biebinger, FabianRohner, Abdeljawad Dib, Christophe Zeder, Richard F Hurrell, Nourredine Chouuki. Vitamin $A$ supplementation in children with poor iron status increases erythropoietin and hemoglobin concentration without changing total body iron. Ame. J. Clin. Nutr. 2006; 84(3), 580-586.

20. Davidson L, Adou P, Zeder C, Walczyk T and Hurrell R. The effect of retinyl palmitate added to iron-fortified maize porridge on erythrocyte incorporation of iron in African children with vitamin $A$ deficiency. Br J Nutr 2003; 90: 337-343.

Source of Support: Nil. Conflict of Interest: None Declared.

Copyright: (c) the author(s) and publisher. IJMRP is an official publication of Ibn Sina Academy of Medieval Medicine \& Sciences, registered in 2001 under Indian Trusts Act, 1882.

This is an open access article distributed under the terms of the Creative Commons Attribution Non-commercial License, which permits unrestricted non-commercial use, distribution, and reproduction in any medium, provided the original work is properly cited.

Cite this article as: Arnab Biswas, Isita Tripathy, Kaberi Basu. Effects on Hematopoiesis in Children Suffering from Iron Deficiency Anemia with Vitamin A Supplementation. Int J Med Res Prof. 2016; 2(5):149-51. 